\title{
Evaluation criteria for research work of students in a foreign language and the principles of their development
}

\section{[Критерии оценки исследовательской работы студентов на иностранном языке и принципы их разработки]}

\author{
Olga Mikhailovna Kozarenko
}

DOI: 10.18355/XL.2019.12.02.16

\begin{abstract}
Students scientific-research conferences in a foreign language are held in almost every University regardless of the direction of training of future specialists. Despite the continuous improvement of their organization, the issue of criteria for the evaluation of student performances is still relevant. However, this aspect is particularly significant both for the creation of the concept of the conference and for the preparation of participants. The present study revealed the lack of clear guidelines in the development of criteria and as a result their imbalance. The selection of a new foreign language research competence helped to fill this gap and to formulate the basic approaches to the development of assessment scales for oral and written statements of students in a foreign language. The proposed criteria were approved by the members of the international jury whose suggestions were taken into account in the final formulation.

Key words: research work of students, foreign languages, evaluation criteria, student conferences, research competence, foreign language competence
\end{abstract}

\begin{abstract}
Аннотация
Научно-исследовательские конференции студентов на иностранном языке проводятся практически в каждом вузе независимо от направления подготовки будущих специалистов. Несмотря на постоянное повышение уровня их организации, проблемным остается вопрос о критериях оценки студенческих выступлений. Но именно этот аспект является особенно значимым, как для создания концепции проведения конференции, так и для подготовки к ней участников. Настоящее исследование обнаружило отсутствие четких принципов при разработке критериев и как следствие их несбалансированность. Выделение новой иноязычной исследовательской компетенции позволило восполнить этот пробел и сформулировать основные подходы в разработке шкалы оценивания устных и письменных высказываний студентов на иностранном языке. Предложенные критерии были апробированы членами международного жюри, пожелания которых были учтены при их окончательной формулировке.

Ключевые слова: исследовательская работа студентов, иностранные языки, критерии оценки, студенческие конференции, исследовательские компетенции, иноязычные компетенции
\end{abstract}

\section{Введение}

\section{Контекст исследования.}

Наиболее активные студенты в среднем участвуют от четырех и более научных конференций на иностранных языках в год, проходящих на вузовских площадках Москвы и других российских городов. Руководство этой работой со стороны преподавателя и организация студентом своей исследовательской деятельности должна определяться четким алгоритмом. Конкурсная основа проведения большинства конференций требует высокого качества 
предоставляемых работ, в котором заинтересованы и студенты, и преподаватели.

Другим важным фактором, стимулирующим развитие исследовательских навыков студентов в рамках предмета «Иностранный язык», является постоянный рост академической мобильности студентов. Для успешной адаптиции в образовательное пространство другой страны от студентов трубуется умение выполнять исследовательские проекты в соответствии с международными требованиями.

\section{Задачи исследования.}

Задачи, которые мы ставили перед собой при проведении настоящего исследования заключались, во-первых, в необходимости повышения качества научных работ студентов, выполненных на иностранном языке. Представление порой достаточно слабых (особенно с исследовательской точки зрения) работ на научные студенческие конференции привело нас к осознанию того, что самым эффективным способом их улучшения будет разработка критериев оценки устных и письменных высказываний, с которыми студенты выступают на конференциях. Именно они служат ориентиром для преподавателей и учащихся при подготовке к участию в работе конференции и в конечном счете определяют ее научный уровень.

Второй важной задачей являлось стремление повысить объективность оценок членов жюри. По нашим наблюдениям, даже на конференциях высокого уровня при приглашении высоко квалифицированных экспертов, их возможности анализа выступления ограничиваются предлагаемыми организаторами критериями оценки. Не следует забывать, что в современных условиях определение призового места является важным бонусом для резюме и рейтинга студента, равно как и для преподавателя, работающего в условиях эффективного контракта.

В-третьих, анализ многочисленных вариантов критериев оценки исследовательской работы учащихся, выполненных на иностранном языке, на наш взгляд, не всегда обнаруживал сбалансированность оценивания исследовательской и иноязычной компетенций студентов.

\section{Гипотеза исследования}

Формулируя гипотезу исследования, мы полагали, что:

1. Разработка оценочной шкалы, опирающаяся на концепцию иноязычной исследовательской компетенции студентов, позволит представить сбалансированное соотношение критериев оценивания различных компетенций.

2. Создание новой шкалы экспертного оценивания устных и письменных высказываний студента на иностранном языке будет максимально способствовать объективности в оценке уровня развития его исследовательских качеств, равно как и владения им иностранным языком специальности.

3. Повышение объективности оценивания позволит студенту лучше понять свои слабые и сильные стороны в рамках обозначенных компетенций и выстроить алгоритм их совершенствования.

4. Новый подход позволит повысить уровень студенческих научных конференций, проводимых на иностранном языке. 


\section{Методы исследования.}

Площадкой для проведения исследования и апробации критериев оценки являлась Международная франкофонная научно-практическая конференция студентов и молодых ученых Франфинанс, которая проходит в Финансовом университете при Правительстве Российской Федерации (г.Москва). Ее концепция была разработана нами еще в 2011 года. Став ежегодной, конференция проводится под эгидой Посольства Франции в России, в 2017 году она проходила и под эгидой Франко-российской торгово-промышленной палаты, что говорит о признании ее высокого уровня.

В конференции принимают участие студенты российских вузов самых различных направлений подготовки. Членами международного жюри являются представители французских деловых и академических кругов, преподаватели специальных и языковых кафедр российских и французских высших учебных заведений, французские студенты-стажеры.

На протяжении всех семи лет проведения конференции проводился мониторинг качества представляемых студентами презентаций (Kozarenko, 2016) и их устных выступлений.

Разработка критериев оценки студенческих выступлений осуществлялась в течение четырех лет. С этой целью ежегодно после проведения конференции проводились групповые и индивидуальные собеседования с членами международного жюри (15-20 чел.), которые высказывали свои пожелания к их содержанию и формулировкам.

На основе изучения шкал оценивания, проводился анализ выставляемых членами жюри баллов, который позволял вносились дальнейшие коррективы.

Во внимание принимался также такой фактор как трудоемкость работы члена жюри, а именно количество времени, которое уходит на выставление баллов по всем оценочным критериям.

В ходе исследования был проведен онлайн опрос российских студентов, проходивших на тот момент стажировку в высших учебных заведениях Франции. Их ответы позволили оценить значимость выполняемой на иностранном языке исследовательской работы для адаптиции к обучению в зарубежном вузе.

\section{Литературный обзор.}

В отечественной и международной литературе авторы достаточно часто обращаются к вопросам организации исследовательской деятельности учащихся. В качестве отдельных примеров можно привести специальные пособия на французском и русском языках (Daniel K. Schneider, 2006; Pastuhova, 2010). Существуют подборки сайтов для франкоговорящих студентов по методике организации исследований (Méthodologie., 2016), которые могут быть полезны при организации франкофонных конференций в российских вузах.

Высоко оценивается значение исследовательской работы при подготовке будущих преподавателей иностранных языков.

Интересными представляются идеи педагогического мониторинга исследовательской активности студентов с помощью портфолио научноисследовательской деятельности студента (Fedorova, 2013) и создания педагогических условий включения студентов в научно-исследовательскую работу при формировании культуры самостоятельной работы (Kozyreva, 2015).

Вопросы разработки оценочных критериев как на родном, так и иностранном языках занимают боле скромное место, несмотря на то, что в Интернете, особенно на профессиональных порталах преподавателей и сайтах для студентов таблицы с критериями оценок исследовательских работ учащихся представлены очень широко. 
Некоторые исследователи, преподающие иностранный язык, обращаются к вопросам оценки проектов, выполненных на иностранном языке (Makarova, 2015; Saranina, , 2013), концентрируя свое внимание, в основном, на содержании и качестве «проектного продукта» школьников и студентов, а порой предъявляя и очень серьезные требования к проведенному исследованию даже в рамках школьной конференции, доказательством чему служат следующие примеры: «четкость формулировки противоречий»; «обозначение диапазона исследований»; «Освоена научная терминология и строго выстроен свой понятийный аппарат» и т.д. (Ozherel'eva, 2012).

В ряде работ отмечается комплексный подход и говорится о необходимости оценки не только языковой компетенции, но и «работы в целом» (Titova, 2013). При этом отмечается, что критерии оценок складываются из трех составляющих: формы; содержания; оценки иностранного языка (ИЯ).

В качестве основных принципов при разработке критериев оценки сформированности профессиональных компетенций в области научноисследовательской деятельности для магистрантов выделяются: принцип сочетания экспертной оценки и самооценки; принцип индивидуального подхода; принцип критериальной ясности (Rudenko, 2013).

Значимость владения исследовательскими компетенциями подчеркивается при разработке рейтинговой системы оценки качества образования и развития творчества студентов (CHuprova, 2013).

\section{Анализ.}

Обратимся к анализу уже используемых на научных студенческих конференциях шкал оценивания исследовательских работ, учащихся на родном и иностранных языках.

Критерии оценивания выступлений на родном языке с разной степенью детализации раскрывают исследовательские компетенции учащихся. Многие из них отдельно оценивают подготовленную презентацию и устное выступление Важным представляется тот факт, что в ряде случаев авторы принимают во внимание использование методов научного исследования и делают акцент на личный вклад автора.

Подробный анализ сравнения критериев оценки исследовательских работ учащихся приведен в Таблице 1 . 
Табл. 1: Сравнение критериев оценки исследовательских работ учащихся на родном языке.

\begin{tabular}{|c|c|c|c|c|}
\hline $\begin{array}{l}\text { Количество } \\
\text { критериев } \\
\text { оценки } \\
\text { работы }\end{array}$ & $\begin{array}{l}\text { Количество } \\
\text { критериев } \\
\text { оценки } \\
\text { выступления }\end{array}$ & $\begin{array}{c}\text { Количес } \\
\text { тво } \\
\text { выставл } \\
\text { яемых } \\
\text { баллов }\end{array}$ & $\begin{array}{l}\text { Особенности формулировок критериев исследовательской } \\
\text { составляющей работ учащихся* }\end{array}$ & Источник \\
\hline 7 & - & 4 & $\begin{array}{l}\text { Планирование; сбор информации; выбор методов; анализ } \\
\text { информации; организация письменной работы }\end{array}$ & $\begin{array}{l}\text { [Krasnoboro } \\
\text { va, 2010) }\end{array}$ \\
\hline 4 & 12 & 3 & Титульный лист; введение; заключение; список литературы & $\begin{array}{l}\text { [Site } \\
\text { wiki.iteach, } \\
2018 \text { ) }\end{array}$ \\
\hline- & 5 & 100 & $\begin{array}{l}\text { Рассуждение и анализ; работа с литературой; применение } \\
\text { идей на практике; организация и структура; общение, умения }\end{array}$ & {$[2010.2)$} \\
\hline 12 & - & 15 & $\begin{array}{l}\text { Правильность оформления научной работы; Актуальность } \\
\text { темы; Применение автором статистического и др. методов } \\
\text { анализа используемого материала; Полнота использованных } \\
\text { литературных источников по теме работы; Глубина } \\
\text { исследования, логичность и ясность изложения, степень } \\
\text { обоснованности выводов и предложений; Анализ } \\
\text { отечественного (и зарубежного - при необходимости) опыта; } \\
\text { Самостоятельность и личный вклад автора в получении } \\
\text { научных результатов; Степень разработанности темы; } \\
\text { Практическая применимость / теоретическая значимость; } \\
\text { Научная новизна, оригинальность авторского подхода и } \\
\text { решений; Апробация и внедрение результатов работы; } \\
\text { Дополнительный балл эксперта }\end{array}$ & $\begin{array}{l}\text { [Site } \\
\text { Financial } \\
\text { University, } \\
\text { 2016) }\end{array}$ \\
\hline 7 & - & 100 & $\begin{array}{l}\text { Знание материала в рамках учебных программ подготовки } \\
\text { бакалавров; Корректность использования понятийного } \\
\text { аппарата; Широта эрудиции; Понимание места и роли } \\
\text { рассматриваемых методов; Логичность изложения: } \\
\text { структурированность текста, наличие в нем четко } \\
\text { выраженных тезисов и аргументов; Знание различных } \\
\text { подходов к решению одной задачи; Наличие личностной } \\
\text { позиции, сделан вывод. }\end{array}$ & $\begin{array}{l}\text { [Site HSE, } \\
\text { 2010. 1) }\end{array}$ \\
\hline 31 & 6 & 30 & 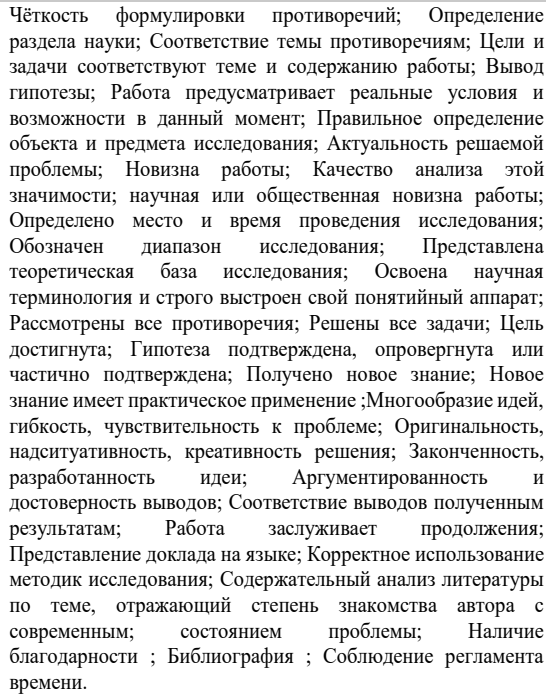 & $\begin{array}{l}\text { [Ozherel'eva } \\
\text {, 2012) }\end{array}$ \\
\hline
\end{tabular}

\section{*некоторые поясняющие формулировки даются в сокращении}


При анализе приведенных выше критериев обращает на себя внимание многозначность некоторых параметров, что может вызывать сложности при выставлении оценок членами жюри. В качестве примера приведем разбор одной из формулировок (Рис. 1).

\section{«лубина исследования, последовательность и ясность изложения, достоверность выводов и предложений »}

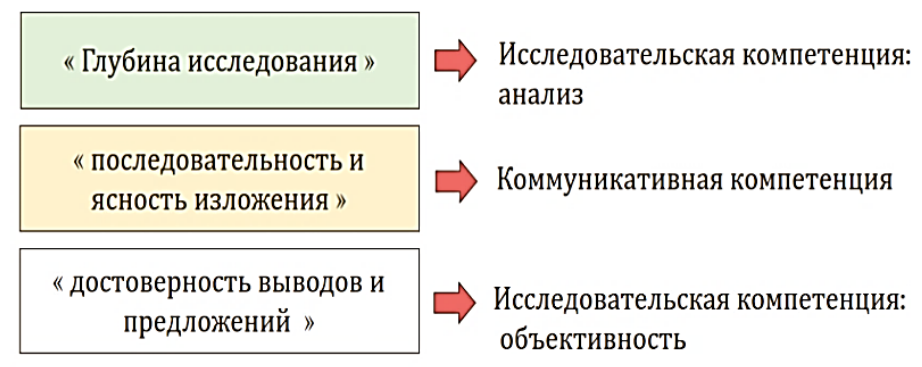

Рис. 1. Пример многозначности формулировки одного из критериев оценки студенческого доклада

В других случаях, для определения критериев характерна очень большая степень обобщённости. Например, формулировки «сбор информации», «выбор методов», в отсутствии четкой расшифровки создают неоднозначность их интерпретации. Некоторые критерии, как например, «Правильное определение объекта и предмета исследования», на наш взгляд, ориентированы больше на искушенного исследователя.

Обращает на себя внимание различие в количестве рассматриваемых критериев, которое колеблется от 4 до 31. В условиях проведения конференции, особенно с большим количеством участников, оценка более чем сорока параметров (с учетом оценки и устного выступления) потребует большого количества времени у членов жюри, что сказывается на регламенте работы конференции.

\section{Анализ критериев оценки выступлений студентов на иностранном языке.}

Мы проанализировали наиболее часто используемые на практике на конференциях в московских вузах шкалы оценивая. Рассмотрим некоторые из них. Первый вариант:

1. Выбор темы: соответствие тематике, ясность

2. Содержание: соответствие, творческий подход, оригинальность

3. Структура: (вступление, основная часть, заключение)

4. Изобразительный ряд: презентация, творческий подход

5. Словарь

6. Грамматика

7. Время выступления

8. Язык жестов

9. Связь с аудиторией

Указанные параметры оцениваются шкалой от 0 до 10 баллов.

Достоинством данного подхода является принятие во внимание таких аспектов, как содержание и оформление работы, характер выступления, простота заполнения. 
Однако, здесь мы сталкиваемся и с некоторыми проблемами. Например, многозначностью в формулировке некоторых параметров. Так критерий «Выбор темы: соответствие тематике, ясность» включает в себя оценку как исследовательской, так и коммуникативной компетенций.

В предложенной шкале есть факторы, по которым практически все участники получают или максимальное количество баллов или минимальное. Речь идет о критериях «Структура работы» и «Язык жестов». Первый из них имеет смысл вводить для школьников или студентов младших курсов, т.к. все более опытные участники конференций его обязательно соблюдают, а, следовательно, им всем будут выставляться максимальные баллы, что будет нивелировать оценочную дифференциацию.

Язык жестов, учитывая сильное волнение участников, практически никто не демонстрирует, а значит, у всех идет минимальная оценка.

Оценивание творческого подхода в предложенных критериях относится только к изобразительному ряду, однако, на наш взгляд, не менее важно проявление творчества и в отражении содержания исследования.

Критерий «Словарь» недостаточно конкретен. Речь идет об уровне владения общим ИЯ, деловым ИЯ или языком специальности? Оценивается богатство словаря письменного или устного высказывания?

Приведем еще один вариант критериев оценки выступления на иностранном языке с пятибалльной системой оценивания:

1. Соответствие темы, структура работы

2. Качество представления материала (свободное изложение или чтение текста)

3. Соответствие/качество презентации

4. Владение иностранным языком

5. Соблюдение времени выступления

При явных достоинствах, которыми являются простота, принятие во внимание содержания выступления его формы и уровня владения выступающим ИЯ, нам бы хотелось обратить внимание на анализ некоторых из них (Табл. 2).

Табл.2. Анализ критериев докладов на иностранном языке

\begin{tabular}{|c|c|}
\hline Критерий & Анализ \\
\hline «Соответствие темы, структура работы» & $\begin{array}{l}\text { Многозначность параметра, отражающее: } \\
\text { качество/содержание исследования и логику изложения }\end{array}$ \\
\hline $\begin{array}{l}\text { «Качество представления материала (свободное } \\
\text { изложение или чтение текста)» и «Владение } \\
\text { иностранным языком» }\end{array}$ & Близкне параметры \\
\hline «Соб.людение времени выступления» & $\begin{array}{l}\text { Затрудняет работу жюри, отвлекая его внимание на } \\
\text { таймер. Часты случан пренебрежения членами жюри } \\
\text { этого критерия. }\end{array}$ \\
\hline «Методы научного исследования» & Отсутствуют \\
\hline
\end{tabular}

При оценке проектных работ, выполненных на английском языке во внимание принимаются такие критерии как: цель; планирование путей достижения цели; раскрытие темы проекта; использование источников информации; анализ рабочего процесса, выводы и вопросы; личный интерес; оформление работы; качество проекта.

Сопоставляя критерии оценок исследовательских работ на родном и иностранном языках, мы видим, что несмотря на более сложный по набору 
компетенций доклад на иностранном языке это не всегда находит отражение при разработке критериев его оценки. При этом набор исследовательских компетенций существенно сокращен.

\section{Оценка исследовательской работы студентов на иностранном языке.}

\section{Содержание исследовательской работы студентов.}

При разработке подходов к оценке исследовательских работ, выполненных на иностранном языке мы исходили из того, что научно-исследовательская или исследовательская работа студентов должна быть ориентирована на:

1. Осознание студентами предназначения науки, как области получения нового знания и понимание сути методов научного познания.

При всей своей очевидности, это положение не всегда осознается студентами особенно младших курсов, а порой и их научными руководителями. В силу этого на конференциях часто можно слышать доклады реферативного типа, лишенные исследовательской составляющей. Отражением этого является также отсутствие проблематики в формулировках студенческих научных докладов (Kozarenko, 2016).

При этом следует учитывать и допускать, что большинство исследовательских работ студентов направлено не столько на получение нового знания, сколько на углубление собственных представлений о предмете исследования. В данном случае «новизна знания» обнаруживается лишь в личностном восприятии студентом изучаемой темы при более глубоком ознакомлении с ней. Тем не менее, студент, проводящий исследование, должен понимать, что, его работа должна быть направлена на посильное решение конкретной проблемы.

Образно говоря, прививая вкус к исследовательской работе, мы должны объяснять молодому исследователю, что пока он идет по одной из узких тропинок, которая в перспективе непременно приведет к широкой дороге, ведущей к обретению объективно нового знания.

На этом пути особенно возрастает роль знакомства молодого человека с научными методами исследования.

2. Ознакомление с методами научного исследования.

Понимание сути различных методов научного исследования является важным ориентиром при определении характера самого исследования, а также способов получения фактических данных, на которые оно должно опираться. Руководитель исследовательской работы студента должен помочь ему в выборе методов с учетом его специальной и лингвистической подготовки. Часто именно этот аспект вызывает наибольшие трудности у преподавателей ИЯ не имеющих ученой степени. В этом случае удачным является соруководство работой студента с преподавателем специальной кафедры.

3. Максимальную активизачию творческой, образовательной и познавательной деятельности молодого исследователя, которая создаст предпосылки для формирования креативного мышления и будет способствовать его творческой самореализачии.

Несмотря на то, что наши студенты часто руководствуются чисто прагматическими соображениями при участии в конференциях, необходимо все время их ориентировать на понимание важности развития их творческого потенциала, формирования исследовательских качеств личности, способной понять проблему, сформулировать ее и найти пути решения.

Учет этих особенностей лежит в основе разработки критериев оценки исследовательской работы студентов, выполненной на иностранном языке.

XLinguae, Volume 12, Issue 2, April 2019, ISSN 1337-8384, eISSN 2453-711X 


\section{Иноязычная исследовательская компетенция студентов.}

Предлагаемая модель экспертной оценки выступления студента на конференции на ИЯ опирается на выше изложенные положения, а также на концепцию иноязычной исследовательской компетенции (ИяИК) (Kozarenko, 2014). Последняя сочетает в себе иноязычную коммуникативную и исследовательскую комптенеции. Ее содержание представлено на Рис.2.

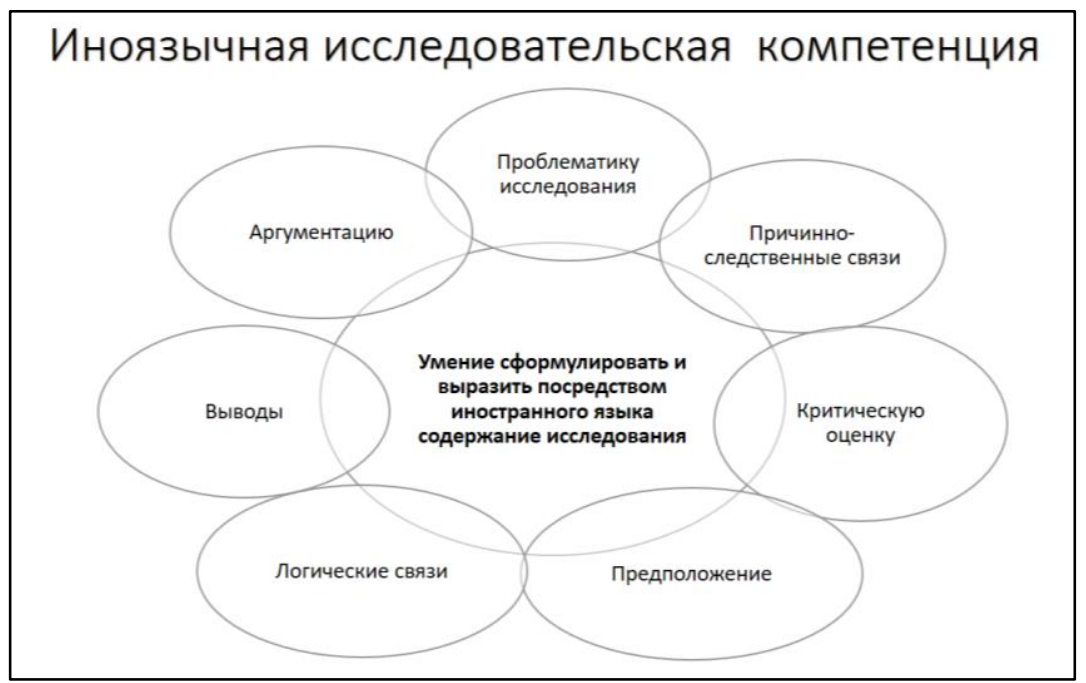

Рис. 2. Содержание иноязычной исследовательской компетенции.

Обратим внимание на возможность двух подходов в использовании иноязычной компетенции студентов при выполнении исследовательской работы (Рис. 3). Преимущество первого подхода заключается в контроле качества проводимого студентом исследования со стороны русскоговорящего преподавателя специальной кафедры. Однако возможности использования иноязычной компетенции учащегося, на наш взгляд, здесь ограничены и сводятся лишь к переводу работы на иностранный язык. Если же мы ориентируемся на развитие Иноязычной исследовательской компетенции, мы получаем гораздо больше возможностей для применения студентом знаний по ИЯ. Однако в этом случае повышаются требования к исследовательским компетенциям преподавателя иностранного языка. 


\section{Варианты подходов в использовании иноязычной компетенции студентов при организации исследовательской деятельности}

I вариант

- На ИЯ переводится студенческое исследование, выполненное на родном языке (под руководством русскоязычного специалиста)

- Совершенствуется компетенция в сфере профессионального перевода (под руководствомпреподавателя ИЯ)
II вариант
Работа со студентом ориентирована на формирование иноязычной исследовательской компетенции:

- Поиск документов на ИЯ

- Систематизацию материалов на ИЯ

- Анализ иноязычной информации

- Перевод на ИЯ русскоязычных материалов по специальности

Рис. 3 Использовании иноязычной компетенции студентов при проведении исследования: варианты подходов

Требования к критериям оценочной шкалы оценивания иноязычной исследовательской компетенции.

Шкала экспертной оценки устных и письменных высказываний студентов на иностранном языке должна отвечать следующим условиям:

1. Ясность формулировок. Формулировки критериев должны быть предельно четкими во избежание различия в их восприятии членами жюри.

2. Детализащия критериев. Четкие разъяснения параметров, которые принимаются во внимании при оценке данного критерия определяют ясность его трактовки, что способствует повышению объективности оценивания.

3. Сбалансированность. При оценке исследовательской работы студентов,выполненной на ИЯ, необходимо учитывать целый ряд факторов, среди которых: уровень сформированности исследовательской и иноязычной компетенций; форма и содержание выступления; умение отвечать на вопросы и вести полемику на ИЯ и т.д. При этом важно найти правильное соотношение между различными видами деятельности, не гипертрофируя одни и не минимизируя другие.

4. Простота заполнения. Даже при многофакторности оценивания, оценочная шкала не должна вызывать серьезные трудности у членов жюри при ее заполнении. В нашей работе соблюдение именно этого фактора вызывало наибольшие трудности. В течение нескольких лет мы стремились максимально оптимизировать работу членов жюри и остановились на предлагаемом ниже варианте только после того, как наиболее строгий из его членов, преподаватель французского вуза, нам не сказал, что работать со шкалой стало просто и удобно. 


\section{Принципы разработки}

В основу разработки критериев оценки выступлений студентов на конференциях на иностранном языке легли следующие принципы:

Табл.3: Основные принципы разработки критериев оценивания исследовательской работы студентов

\begin{tabular}{|c|c|}
\hline Принципы & Содержание \\
\hline $\begin{array}{l}\text { Соответствие формату } \\
\text { мероприятия }\end{array}$ & $\begin{array}{l}\text { Шкала экспертной оценки должна соответствовать статусу меропрнятия } \\
\text { (конкурс нсследовательскнх проектов, научная конференция, конкурс } \\
\text { научных презентаций) и т.д. }\end{array}$ \\
\hline Междисциплинарный подход & $\begin{array}{l}\text { Крнтерни должны учитывать не только компетенций в области ИЯ, но и } \\
\text { уровень знаний по специальности, владенне професснональными ИКТ } \\
\text { компетенциями (Каshchuk, 2018), уменне использовать ннформацнонные } \\
\text { компетенции для макснмального раскрытия когнитивных способностей } \\
\text { обучаемых (Kozarenko, 2018). }\end{array}$ \\
\hline $\begin{array}{l}\text { Сочетание качественных и } \\
\text { количественных характеристикс } \\
\text { градацией параметров оценки }\end{array}$ & $\begin{array}{l}\text { Каждый из критернев должен сопровождаться четкой количественной } \\
\text { регламентацией. Член жюри должен поннмать каким количеством баллов } \\
\text { оценивается данный критерий по мере возрастания его трудности. }\end{array}$ \\
\hline Вариативность & $\begin{array}{l}\text { В рамках одного меропрнятня критерни могут варьнровать в завнснмости } \\
\text { от формы участия (очное выступленне, стендовый доклад, групповое } \\
\text { выступленне и т.д.), возрастных особенностей участннков (например при } \\
\text { выделенин секции для школьннков); уровня владення языковыми } \\
\text { компетенциями (первый язык, второй язык). }\end{array}$ \\
\hline Актуализация & $\begin{array}{l}\text { По мере развития исследовательских навыков участников следует } \\
\text { пересматривать и усложнять требовання к критерням оценивания. Это } \\
\text { позволит с одной стороны избегать выставлення одинаковых баллов } \\
\text { участникам за хорошо освоенный вид деятельностн, а с другой будет } \\
\text { способствовать повышенню мотивацин участников в выполненни работ на } \\
\text { более высокомуровне. }\end{array}$ \\
\hline $\begin{array}{l}\text { Побуждение к творческой } \\
\text { самореализации личности }\end{array}$ & $\begin{array}{l}\text { Независнмо от колнчества набранных баллов, каждый нз участников, } \\
\text { поняв свон сильные и слабые стороны в результате оценкн его работы, } \\
\text { должен осознать необходимость в дальнейшей реализацин его творческого } \\
\text { потенциала. }\end{array}$ \\
\hline
\end{tabular}

\section{Оценочная шкала экспертной оценки выступления студентов на иностранном языке на конференции.}

С учетом выше сказанного нами была разработана шкала экспертной оценки студенческих выступлений на иностранном языке на студенческой конференции (Рис.4). 


\begin{tabular}{|c|c|c|c|c|}
\hline & & $\begin{array}{l}\text { Секция } \\
\text { Студент: фамилия, имя } \\
\text { Эксперт: фамилия, имя }\end{array}$ & & \\
\hline & & ритерии оценки студенческого доклада на иностранном языке & & \\
\hline № & Критерии & Характеристика показателей & $\begin{array}{c}\text { 3начен } \\
\text { ия }\end{array}$ & $\begin{array}{c}\text { Начислен } \\
\text { ные баллы }\end{array}$ \\
\hline 1. & Содержание & Не соответствует заявленной теме/Соответствует & $0 / 1$ & \\
\hline & доклада & $\begin{array}{l}\text { Проб̆лематика отсутствует/ } \\
\text { Есть проблематика: исследование направлено на решение конкретной проблемы }\end{array}$ & $0 / 2$ & \\
\hline & & Стандартная формулировка темы /0ригинальная формулировка темы & $0 / 1$ & \\
\hline 2. & $\begin{array}{l}\text { Использованные } \\
\text { методы научного }\end{array}$ & $\begin{array}{l}\text { Автор не использовал МНИ/Автор использовал: наблюдение, } \\
\text { сравнение/обобщение, анкетирование, эксперимент }\end{array}$ & $0 / 1 / 2$ & \\
\hline & $(М H И)$ & $\begin{array}{l}\text { Отсутствие статистических данных/ } \\
\text { Статистические данные без анализа / } \\
\text { Анализ статистических данных/Глубокий анализ данных с оригинальными } \\
\text { выводами }\end{array}$ & $0 / 1 / 2 / 3$ & \\
\hline & & $\begin{array}{l}\text { Графики, таблицы, диаграммы заимствованы/ } \\
\text { Графики, таблицы, диаграммы составлены самостоятельно автором }\end{array}$ & $1 / 2$ & \\
\hline 3. & $\begin{array}{l}\text { Глубина } \\
\text { проведенного } \\
\text { исследования }\end{array}$ & $\begin{array}{l}\text { Описание явлений / } \\
\text { Анализ («за» и «против»; сравнение; преимущества/недостатки) } \\
\text { (по мере возрастания глубины исследования) }\end{array}$ & $1 / 2$ & \\
\hline 4. & $\begin{array}{l}\text { Использованные } \\
\text { источники } \\
\text { информации }\end{array}$ & $\begin{array}{l}\text { Количество использованных источников, процитированных в презентации: } \\
\text { до 4/до 6/ } 10 \text { и более }\end{array}$ & $1 / 2$ & \\
\hline 5. & $\begin{array}{l}\text { Ссылки на } \\
\text { источники }\end{array}$ & $\begin{array}{l}\text { Есть документы без ссылок / } \\
\text { Каждый документ сопровождается ссылкой }\end{array}$ & $0 / 1$ & \\
\hline 6. & $\begin{array}{l}\text { Уровень } \\
\text { коммуникативной } \\
\text { компетенции }\end{array}$ & $\begin{array}{l}\text { Чтение доклада. Отсутствие контакта с публикой/ } \\
\text { Трудности в изложении и общении/ } \\
\text { Свободное высказывание }\end{array}$ & $1 / 2 / 3$ & \\
\hline & & $\begin{array}{l}\text { Интерактивность: } \\
\text { Нет общения с аудиторией /свободное общение с аудиторией } \\
\text { (по мере возрастания свободы общения) }\end{array}$ & $1 / 2 / 3$ & \\
\hline 7. & $\begin{array}{l}\text { Уровень научной } \\
\text { презентации }\end{array}$ & $\begin{array}{l}\text { Структура презентации: } \\
\text { Соблюдена (есть план: введение, основная часть, выводы, } \\
\text { библиография)/нарушена / (плохо составленный план), отсутствие заключения, } \\
\text { библиографии, }\end{array}$ & $0 / 1$ & \\
\hline & & $\begin{array}{l}\text { Типовая презентация/ } \\
\text { Творческая презентация (оригинальный стиль; отражает личность автора) } \\
\text { ( в соответствии с творческой составляющей) }\end{array}$ & $1 / 2 / 3$ & \\
\hline 8. & $\begin{array}{l}\text { Уровень владения } \\
\text { деловым ИЯ }\end{array}$ & $\begin{array}{l}\text { Использование иноязычной экономических терминов (по мере возрастания } \\
\text { сложности) }\end{array}$ & $1 / 2 / 3$ & \\
\hline & & Выражение собственной точки зрения на затронутую проблему & $0 / 1$ & \\
\hline & & Критические высказывания & $0 / 1$ & \\
\hline & & $\begin{array}{l}\text { Языковая грамотность: } \\
\text { Письменного изложения } \\
\end{array}$ & $1 / 2 / 3$ & \\
\hline & & $\begin{array}{l}\text { Устного высказывания } \\
\text { (по мере увеличения грамотности высказывания) }\end{array}$ & $1 / 2 / 3$ & \\
\hline 9. & $\begin{array}{l}\text { Ответы на } \\
\text { заданные вопросы } \\
\text { (относится в } \\
\text { первую очередь к } \\
\text { вопросам членов } \\
\text { жюри) }\end{array}$ & $\begin{array}{l}\text { Вопрос остался без ответа и комментария/Нечеткий ответ/Полный } \\
\text { аргументированный ответ }\end{array}$ & $0 / 1 / 2$ & \\
\hline 10 & $\begin{array}{l}\text { Дополнительный } \\
\text { бал за неучтенный } \\
\text { критерий }\end{array}$ & Не более одного балла (просьба дать пояснения) & $0 / 1$ & \\
\hline & СУММА & (максимум: 40 баллов) & & \\
\hline
\end{tabular}

Рис. 4. Критерии оценки студенческого доклада на иностранном языке.

XLinguae, Volume 12, Issue 2, April 2019, ISSN 1337-8384, eISSN 2453-711X 
Следуя принципу вариативности эта шкала может быть упрощена с учетом уровня языковой подготовки и сформированности исследовательской компетенции участников. Например, для студентов младших курсов для нее можно внести изменения, представленные на Рис.5.

\begin{tabular}{|c|c|c|c|}
\hline \multirow[t]{2}{*}{2.} & \multirow[t]{2}{*}{$\begin{array}{l}\text { Использованные } \\
\text { методы научного } \\
\text { исследования }\end{array}$} & $\begin{array}{l}\text { Отсутствие статистических данных/ } \\
\text { Статпстпгескіе данные без анализа / } \\
\text { Анализ статистпческих данньх }\end{array}$ & $0 / 1 / 2$ \\
\hline & & $\begin{array}{l}\text { Графпки, таблгцы, дпаграммы занмствованы/ } \\
\text { Графпки, таблшцы, дпаграммы составлены самостоятельно автором }\end{array}$ & $1 / 2$ \\
\hline 3. & $\begin{array}{l}\text { Глубина } \\
\text { проведенного } \\
\text { исследования }\end{array}$ & $\begin{array}{l}\text { Описание явлений / } \\
\text { Анализ (« за» п « протпв»; сравненше; препмущества/недостатки) } \\
\text { (по мере возрастания глубины псследованпя) }\end{array}$ & $1 / 2 / 3$ \\
\hline 4. & $\begin{array}{l}\text { Использованные } \\
\text { источники } \\
\text { инфориации }\end{array}$ & $\begin{array}{l}\text { Количество использованных источников, процитированных в презентации: } \\
\text { до } 3 / \text { более } 3\end{array}$ & $1 / 2$ \\
\hline 5. & $\begin{array}{l}\text { Ссиики на } \\
\text { источники }\end{array}$ & $\begin{array}{l}\text { Есть документы без ссылок / } \\
\text { Каждый документ сопровождается ссылкой }\end{array}$ & $0 / 1$ \\
\hline
\end{tabular}

Рис. 5. Пример упрощения параметров оценки для студентов младших курсов.

В случае конкурса групповых презентаций можно внести дополнительный критерий «Работа в группе» $1 / 2 / 3$.

Организация работы с критериями экспертной оценки.

Несомненно, что и участники конференции, и члены жюри должны быть ознакомлены заранее с критериями оценок. Однако опыт показывает, что представление студентам шкалы с количественными параметрами может вызывать формальную «подгонку» работы под наивысшие значения.

Членам жюри целесообразно заранее выслать оценочную шкалу для предварительного ознакомления. В этом случае до начала конференции они получают возможность задать все вопросы и уточнить неясные моменты. Следует обратить внимание членов жюри на то, что после выступления студента ему обязательно следует задавать вопросы, т.к. ответы студентов оцениваются. Этот критерий является крайне важным, т.к. позволяет оценить спонтаннойсть реакции на иноязычное высказывание и умение вести дискуссию на иностранном языке.

В случае явного несоответствия количества выставленных баллов членом жюри и качеством выступления студента, состав жюри может обратиться к эксперту с просьбой дать необходимые разъяснения.

Важно учитывать социокультурные особенности в организации работы международного жюри (Kozarenko, 2017).

По соображениям научной этики, преподаватель не может оценивать студенческую работу, руководителем которой он является.

Некорректно также оцение работы экспертом, имеющим более низкий научный статус по сранению с руководителем работы студента (не кандидат наук оценивает работу, выполненную под руководством кандидата наук).

Подсчет суммы баллов может производиться каждым членом жюри или специально выделенной счетной комиссией на каждой секции. Целесообразно вести подсчет в процессе работы секции. Окончательное решение по определению призовых мест осуществляется всеми членами жюри данной секции на основании подсчитанного количества баллов за каждое выступление. 


\section{Выводы.}

По мнению приглашенных экспертов, использование разработанной шкалы оценивания исследовательской работы студентов на иностранном языке позволило повысить уровень и качество представляемых ими работ.

Полученный опыт по проведению исследований на иностранном языке (анализ большого количества иноязычных источников, работа с информацией на ИЯ, ее систематизация, опыт публичных выступлений и т д.) по мнению студентов, помог им при прохождении стажировок в рамках академической мобильности.

Многолетняя апробация и работа по совершенствованию оценочной шкалы, на наш взгляд, во многом способствовала формированию высокого статуса конференции Франфинанс.

Для соответствия указанным критериям преподавателями должна вестись планомерная работа по формированию Иноязычной исследовательской компетенции на протяжении всего периода обучения студентов.

Публикация подготовлена при поддержке программы РУДН «5-100». / The publication was prepared with the support of the «RUDN University Program 5-100».

\section{Bibliographic references}

CHUPROVA L. V. - ERSHOVA O. V. 2013. Rejtingovaya sistema ocenki kachestva obrazovaniya kak faktor razvitiya tvorcheskoj aktivnosti studentov. Internet-zhurnal Naukovedenie. $\quad$ n. 4 (17). 73 p. Available online: http://cyberleninka.ru/article/n/reytingovaya-sistema-otsenki-kachestva-obrazovaniyakak-faktor-razvitiya-tvorcheskoy-aktivnosti-studentov ISSN: 2223-5167

DANIEL K. SCHEIDER, 2006. Balises de methodologie pour la recherche en sciences sociales. Matériaux de cours en plusieurs modules. Genève. Version 1.1 juillet (C) DKS 6/7/06

Available online: http://tecfa.unige.ch/guides/methodo/IDHEAP/methodes.book.pdf

KOZARENKO, O. M. 2014. Inoyazychnaya issledovatel'skaya kompetenciya: osobennosti soderzhaniya i formirovaniya. Teoriya i praktika obucheniya inostrannym yazykam v neyazykovom vuze: tradicii, innovacii, perspektivy. Finansovyj universitet Moskva, pp. 140-151. ISBN 978-5-7942-1236-5

KOZARENKO, O. M. 2016. Analiz nauchnogo diskursa studencheskih prezentacij na francuzskom yazyke. In: YAzyk i dejstvitel'nost'. Nauchnye chteniya na kafedre romanskih yazykov im. V.G. Gaka Sbornik statej po itogam mezhdunarodnoj konferencii. pp. 83-87. ISBN: 978-5-4263-0340-9

KOZARENKO, O. M. Rabota zhyuri na studencheskoj mezhdunarodnoj konferencii: kak povysit' ob"ektivnost' ocenki? Mezhdunarodnaya nauchno-prakticheskaya konferenciya «YAzyk. Kul'tura. Perevod. Kommunikaciya» 2.11. - 3. 11. 2017 (in the publication)

KOZYREVA, O. A. 2015. Specifika sozdaniya pedagogicheskih uslovij vklyucheniya budushchego pedagoga $\mathrm{v}$ nauchno-issledovatel'skuyu rabotu. In: Vestnik KemGU. n. 2-3 (62). Available online: http://cyberleninka.ru/article/n/spetsifika-sozdaniyapedagogicheskih-usloviy-vklyucheniya-buduschego-pedagoga-v-nauchnoissledovatelskuyu-rabotu. ISSN 2078-8975

KRASNOBOROVA, A.A. 2010. Kriterii ocenivaniya proektnoj deyatel'nosti uchashchihsya. In: Lichnost', sem'ya i obshchestvo: voprosy pedagogiki i psihologii: sb. st. po mater. II mezhdunar. nauch. -prakt. konf. N. 2. CHast' I. - Novosibirsk: SibAK,

KRITERII, (1) proverki rabot uchastnikov Olimpiady dlya studentov i vypusknikov vuzov «Kompleksnyj social'nyj analiz», «Prikladnye metody social'nogo analiza

XLinguae, Volume 12, Issue 2, April 2019, ISSN 1337-8384, eISSN 2453-711X 
rynkov», «Sociologiya publichnoj sfery i social'nyh kommunikacij». HSE.2011, «Demografiya». Available online: https://talent.hse.ru/olimp/ma/2011/crit

KRITERII, (2) proverki rabot uchastnikov Olimpiady dlya studentov i vypusknikov vuzov. HSE.2011, «Mirovaya ehkonomika». Available online: https://talent.hse.ru/olimp/ma/2011/crit

MAKAROVA, L. A. 2015. Obuchenie vypolneniyu i ocenivanie proektov na anglijskom yazyke. In : Molodoj uchenyj. n. 14. pp. 492-494. Available online: https://moluch.ru/archive/94/21078/. ISSN 2072-0297

METODOLOGIE de la recherche : guide du jeune chercheur en lettres, langues, sciences humaines et sociales, Ellipses. 2016. Novembre Site : ENPJJ / Service de la recherche et de la documentation / Mediatheque

Available

online:

http://www.enpjj.justice.fr/mediatheque/documents/portail/texte/bibliographies/Métho dologie\%20de\%201a\%20recherche\%20scientifique.pdf.

OZHEREL'EVA, L. A. 2012. Kriterii ocenki issledovatel'skih rabot uchashchihsya na nauchno-(issledovatel'skoj) prakticheskoj konferencii. Available online: https://nsportal.ru/shkola/inostrannye-yazyki/angliiskiy-

azyk/library/2012/08/23/kriterii-otsenki-issledovatelskikh

OCENIVANIE, issledovatel'skih rabot. Available online: http://wiki.iteach.ru/images/b/be/Ocenivanie_issledovatel'skih_rabot.pdf.

PASTUHOVA, I. P. - TARASOVA, N.V. 2010. Osnovy uchebno-issledovatel'skoj deyatel'nosti studentov : ucheb. -metod. posobie dlya stud. sredn. prof. ucheb. zavedenij M.: Izdatel'skij centr «Akademiya», 160 p. 15VN 978-5-7695-6040-8

RUDENKO, I. V. 2013. Problema formirovaniya i ocenivaniya professional'nyh kompetencij v oblasti nauchno-issledovatel'skoj deyatel'nosti studentov magistratury In : Vektor nauki Tol'yattinskogo gosudarstvennogo universiteta. Seriya: Pedagogika, psihologiya. n.1 (12). Available online: http://cyberleninka.ru/article/n/problemaformirovaniya-i-otsenivaniya-professionalnyh-kompetentsiy-v-oblasti-nauchnoissledovatelskoy-deyatelnosti-studentov. ISSN: 2221-5662

SARANINA, I. I. 2013. Kriterii samoocenivaniya v proektnoj deyatel'nosti uchashchihsya pri izuchenii inostrannogo yazyka. Vestnik RUDN. Seriya: Voprosy obrazovaniya. YAzyki i special'nost'. n. 1. Available online: http://cyberleninka.ru/article/n/kriterii-samootsenivaniya-v-proektnoy-deyatelnostiuchaschihsya-pri-izuchenii-inostrannogo-yazyka. ISSN: 2312-8011

SITE, Financial University.V Mezhdunarodnyj konkurs nauchnyh rabot aspirantov i studentov. Kriterii ocenki nauchnoj raboty. Finuniversitet. Available online: http://economy.ranepa.ru/new/wp-content/uploads/2016/02/2016-Informpismo-2-.pdf TITOVA, Marina Igorevna. 2013. Kriterii ocenok proektnyh rabot po anglijskomu yazyku dlya studentov special'nosti "Informatika". Available online: https://nsportal.ru/shkola/inostrannye-yazyki/angliiskiy-

yazyk/library/2013/03/24/kriterii-otsenok-proektnykh-rabot-po. Data obrashcheniya: 05.02 .2018

FEDOROVA, M. A. 2013. Portfolio nauchno-issledovatel'skoj deyatel'nosti studenta. In: Vysshee obrazovanie v Rossii. n. 8-9. pp.158-160. ISSN: 0869-3617

Words: 3544

Characters: 30206 (16,78 standard pages)

Ph. D., associate Professor Olga Mikhailovna Kozarenko

Department of theory and practice of foreign languages

Institute of foreign languages, Peoples ' friendship University of Russia

7, Miklukho-Maklaya St., Moscow 117198

Russia

kozarenko_om@rudn.university 